\author{
ACTA MYCOLOGICA \\ Vol. 43 (1): 57-65 \\ 2008
}

\title{
Glomus eburneum and Scutellospora fulgida, species of arbuscular mycorrhizal fungi (Glomeromycota) new for Europe
}

\author{
JANUSZ BLASZKOWSKI and BEATA CZERNIAWSKA
}

Department of Plant Pathology, University of Agriculture in Szczecin

Słowackiego 17, PL-71-434 Szczecin, jblaszkowski@agro.ar.szczecin.pl

Błaszkowski J., Czerniawska B.: Glomus eburneum and Scutellospora fulgida, species of arbuscular mycorrhizal fungi (Glomeromycota) new for Europe. Acta Mycol. 43 (1): 57-65, 2008.

Morphological characters of spores and mycorrhizae of Glomus eburneum and spores of Scutellospora fulgida, arbuscular mycorrhizal fungi of the phylum Glomeromycota, are described and illustrated. Additionally, the known distribution of these species in both Poland and other regions of the world is presented. Both species were not earlier reported from Europe.

Key words: Glomus eburneum, Glomeromycota, Scutellospora fulgida, occurrence

\section{INTRODUCTION}

Examination of pot trap cultures with mixtures of rhizosphere soils and roots collected in Poland and other regions of the world revealed spores of Glomus eburneum L.J. Kenn., J.C. Stutz et J.B. Morton and Scutellospora fulgida Koske et C. Walker, arbuscular mycorrhizal fungi of the phylum Glomeromycota. Both species were not earlier reported from Europe.

The aims of this paper are to describe and illustrate these species and present their distribution in both Poland and the world.

\section{MATERIALS AND METHODS}

Establishment and growth of trap and one-species cultures, extraction of spores, and staining of mycorrhizae. Spores examined in this study came from both pot trap and one-species cultures. Trap cultures were established to obtain a great number of living spores of different developmental stages and to initiate sporulation of species that were present but not sporulating in the field collections (Stutz, Morton 1996). The method used to establish trap cultures, their growing conditions, and the method of spore extraction were previously described (Błaszkowski et al. 2004, 2006). 
One-species cultures were also generally established and grown as given in Błaszkowski et al. (2004), with two exceptions. First, instead of marine sand, their growing medium was an autoclaved commercially available coarse-grained sand (grains 1.0-10.0 mm diam. - 80.50\%; grains 0.1-1.0 mm diam. - 17.28\%; grains < $0.1 \mathrm{~mm}$ diam. - 2.22\%) mixed $(5: 1, \mathrm{v} / \mathrm{v})$ with clinopthilolite (Zeocem, Bystré, Slovakia) of grains $2.5-5 \mathrm{~mm}$. Clinopthilolite is a crystaline hydrated alumosilicate of alkali metals and alkaline earth metals having, e.g., a high ion exchange capability and selectivity, as well as a reversible hydration and dehydration. $\mathrm{pH}$ of the sandclinopthilolite mixture was 7.3. Second, the cultures were kept in transparent plastic bags, $15 \mathrm{~cm}$ wide and $22 \mathrm{~cm}$ high as suggested by Walker and Vestberg (1994), rather than open pot cultures (Gilmore 1968). To prevent contamination of the cultures with other AMF but still to allow exchange of gases, we left an opening, $c a .1 \mathrm{~cm}$ wide, in the centre of the upper part of each bag, while the edges on both sides were closed with small plastic clips. The cultures were watered with tap water once a weak, harvested after five months when spores were extracted for study. To reveal mycorrhizae, root fragments located $c a$. $1-5 \mathrm{~cm}$ below the upper level of the growing medium were cut off with a scalpel. The host plant used in both trap and one-species cultures was Plantago lanceolata L.

Microscopy survey. Morphological properties of spores and their wall structure were determined based on examinations of at least 100 spores mounted in polyvinyl alcohol/lactic acid/glycerol (PVLG; Omar, Bollan and Heather 1979) and a mixture of PVLG and Melzer's reagent $(1: 1, \mathrm{v} / \mathrm{v})$. Spores at all developmental stages were crushed to varying degrees by applying pressure to the cover slip and then stored at $65^{\circ} \mathrm{C}$ for $24 \mathrm{~h}$ to clear their contents from oil droplets. These were then examined under an Olympus BX 50 compound microscope equipped with Nomarski differential interference contrast optics. Microphotographs were recorded on a Sony 3 CDD color video camera coupled to the microscope.

Terminology of spore structure is that suggested by Stürmer and Morton (1997) and Walker (1983). Spore colour was examined under a dissecting microscope on fresh specimens immersed in water. Colour names are from Kornerup and Wanscher (1983). Nomenclature of fungi and plants is that of Walker and Trappe (1993) and Mirek et al. (1995), respectively. The authors of the fungal names are those presented at the Index Fungorum website http://www.indexfungorum.org/AuthorsOfFungalNames.htm. Specimens were mounted in PVLG on slides and deposited in the Department of Plant Pathology, University of Agriculture, Szczecin, Poland.

Colour microphotographs of spores and mycorrhizae of the fungi presented here can be viewed at the URL http://www.agro.ar.szczecin.pl/ jblaszkowski/.

\section{DESCRIPTIONS OF THE SPECIES}

Glomus eburneum L.J. Kenn., J.C. Stutz et J.B. Morton

Sporocarps unknown. Spores occur singly in the soil (Fig. 1); origin blastically at the tip of hyphae continuous with extraradical mycorrhizal hyphae. Spores yellowish white (4A2) to butter yellow (4A5); globose to subglobose; (92-)108(-146) $\mu \mathrm{m}$ diam; or ovoid; 104-115 x 123-139 $\mu \mathrm{m}$; with one subtending hypha (Figs 1, 2, 5 and 6). Subcellular structure of spores consists of a spore wall composed of two tightly adherent layers (layers 1 and 2; Figs 2-5). Layer 1, forming the spore surface, semi- 
permanent, semi-flexible, hyaline, (0.7-)1.0(-1.2) $\mu \mathrm{m}$ thick, frequently intact or only slightly deteriorated in mature spores, sometimes associated with granular soil debris. Layer 2 laminate, semi-flexible, smooth, yellowish white (4A2) to butter yellow (4A5), (2.5-)3.5(-4.4) $\mu \mathrm{m}$ thick. None of the two layers stains in Melzer's reagent. Subtending hypha yellowish white (4A2) to butter yellow (4A5); straight or recurved; cylindrical or slightly flared, sometimes slightly constricted; (7.8-)9.9(-14.0) $\mu \mathrm{m}$ wide at the spore base (Figs 1, 5 and 6). Wall of subtending hypha yellowish white (4A2) to butter yellow (4A5); (1.0-)1.6(-2.7) $\mu \mathrm{m}$ thick at the spore base; composed of two layers continuous with spore wall layers 1 and 2 (Fig. 5). Pore 3.8-5.1 $\mu \mathrm{m}$ diam. open or occluded by a straight or recurved septum, (1.0-)1.4(-2.0) $\mu \mathrm{m}$ thick, continuous with the innermost laminae of the laminate spore wall layer 2, positioned up to 11.3 $\mu \mathrm{m}$ below the spore base (Figs 5 and 6). Germination. Not observed.

MyCORRHIZAL ASSOCIATIONS. The presence of mycorrhizae in field-collected root samples was not determined.

In one-species cultures with $P$. lanceolata as the host plant, mycorrhizae of $G$. eburneum comprised arbuscules, as well as intra- and extraradical hyphae. Arbuscules consisted of short trunks branched from parent hyphae and numerous branches with very fine tips (Figs 7 and 8). Their distribution along root fragments ranged from uniform to patchy, depending on the root fragment examined. Intraradical hyphae grew along root axis, were (2.0-)4.9(-8.3) $\mu \mathrm{m}$ wide and sometimes formed Y- or H-shaped branches and coils (Figs 7 and 8). The coils were ellipsoid, 10.5$23.3 \times 36.8-57.4 \mu \mathrm{m}$, when observed in a plane view. Extraradical hyphae were (2.7-) 3.1(3.4) $\mu \mathrm{m}$ wide and occurred very rarely and in low abundances. In $0.1 \%$ trypan blue, arbuscules stained violet white (15A2) to light lilac (16A5), intraradical hyphae violet white (16A2) to pale violet (16A3), coils lilac (16A5) to royal purple (16D8), and extraradical hyphae violet white (16A2) or remained unstained.

Phylogenetic Position. Kennedy, Stutz and Morton (1999) concluded that the lack of vesicles and the faintly staining other components of mycorrhizae of G. eburneum are untypical of most species of the genus Glomus, but are characteristic for, e. g., Archaeospora trappei (R.N. Ames et Linderman) J.B. Morton et D. Redecker emend. Spain, Appendicispora gerdemannii (S.L. Rose, B.A. Daniels et Trappe) Spain, Oehl et Sieverd. and Diversispora spurca (C.M. Pfeiff., C. Walker et Bloss) C. Walker et Schuessler, of which the former two fungi come from the order Archaeosporales C. Walker et Schuessler and the latter one has recently been accommodated in the family Diversisporaceae C. Walker and Schuessler of the order Diversisporales C. Walker et Schuessler (Schüßler, Schwarzott and Walker 2001; Spain, Sieverding and Oehl 2006; Walker and Schüßler 2004). Gamber and Leuchtmann (2007) found the INVAM isolate AZ420A of G. eburneum to be in a sister position to G. versiforme (P. Karsten) S.M. Berch, being phylogenetically most closely related to D. spurca (Schwarzott, Walker and Schüßler 2001).

Distribution AND HABitAT. In Poland, spores of G. eburneum were found in only one trap culture containing a mixture of rhizosphere soil and root fragments taken from under Helichrysum areanarium (L.) Moench growing in maritime sand dunes of the Słowiński National Park $\left(54^{\circ} 45^{\prime} \mathrm{N}, 1^{\circ} 26^{\prime} \mathrm{E}\right)$ on 26 June 2003 . The occurrence of spores of arbuscular fungi in the field sample was not investigated. The species of arbuscular fungi co-occurring with G. eburneum in the trap culture were Archaeospora 
trappei (R.N. Ames et Linderman) J.B. Morton et D. Redecker emend. Spain and G. lamellosum Dalpé, Koske et Tews.

The holotype of G. eburneum has been selected from spores extracted from the INVAM culture AZ420A established from a mixture of rhizosphere soil and root fragments of Sporobolus wrightii Monro ex Scribn. growing along the San Pedro River in Arizona, U.S.A. (Kennedy, Stutz and Morton 1999). Sporobolomyces wrightii is a native grass species found only along rivers and streams of the semiarid regions of south-western North America. Additionally, the same scientists and Stutz et al. (2000) recorded this fungus among roots of other plants growing in other sites of Arizona and Mexico, as well as under different plant species colonizing a dune transect in the Namibia desert.

Collections examined. Poland: Szczecin, under pot-cultured P. lanceolata, 10.02.2005, J. Błaszkowski 2682-2696 (DPP).

Notes. The most distinctive characters of G. eburneum are its light-coloured spores filled with dense, opaque oil substance and the semi-flexible, 2-layered spore wall with the outermost layer nonreactive in Melzer's reagent and usually remaining more or less intact in mature spores (Figs 1-6).

When observed at a low magnification, spores of G. eburneum are most reminiscent of those of D. spurca, G. albidum C. Walker et L.H. Rhodes, G. gibbosum Błaszk., G. viscosum Nicol., and Paraglomus occultum (C. Walker) J.B. Morton et D. Redecker. Darker-coloured spores of G. eburneum may also be confused with lightpigmented spores of G. claroideum N.C. Schenck et S.M. Sm. and G. versiforme.

Except for G. versiforme, examination of spores crushed in PVLG and PVLG mixed with Melzer's reagent under a compound microscope readily separates G. eburneum from all the other species listed above. Considering the spore wall structure, as well as the phenotypic and biochemical properties of its components, the fungus most closely related to G. eburneum is $D$. spurca. Although the opinions of the number of layers overlaying the laminate spore wall layer of $D$. spurca are contradictory (one layer according to Kennedy, Stutz and Morton 1999 and Morton 2002 vs. two layers as Błaszkowski (2003) stated), the laminate layer and the layer directly overlaying it are almost identical in both their phenotypic and biochemical properties. The main differences between these fungi hide in the persistency of the spore wall layers directly covering the structural laminate layer and the degree of the association of these layers with the laminate layer. Consequently, the second property defines the basic differences in the persistency of the subtending hyphae of both fungi.

Although the outer spore wall layer is relatively long-lived and usually retains as a more or less deteriorated structure in mature spores of G. eburneum (Figs 2-5), its spatially corresponding spore wall layer in $D$. spurca is more persistent and always remains intact in even old spores (Błaszkowski 2003; Kennedy, Stutz and Morton 1999).

In G. eburneum, the outer spore wall layer always remains tightly adherent to the laminate spore wall layer (Figs 2-5), whereas the semi-flexible layer directly covering the laminate spore wall layer of $D$. spurca easily separates in crushed spores or balloons when immersed in lactic acid-based mountants (Błaszkowski 2003; Kennedy, Stutz and Morton 1999). 
In G. eburneum, the structural layer of the subtending hyphal wall (shwl2) continuous with the laminate spore wall layer and being the support of the outer thin wall layer of the subtending hypha gradually thins and expands up to $25 \mu \mathrm{m}$ below the spore base (Fig. 5). In contrast, in D. spurca spores, the laminate spore wall layer abruptly thins and stops to grow at their base and, thereby, it does not create a sufficient support to stabilize the outer subtending hyphal wall layer continuous with the spore wall layer 2 sensu Błaszkowski (2003). Therefore, almost all crushed spores of $D$. spurca usually lack the subtending hypha, which detaches along with the outer wall layer of these spores.

Finally, in contrast to the opaque, frequently yellow-coloured contents of G. eburneum spores, the spore contents of $D$. spurca consists of transparent oil droplets.

Compared with G. albidum described to also form a 2-layered spore wall of similar phenotypic characters (Walker, Rhodes 1981) to those of the wall layers of spores of G. eburneum, spores of the latter species do not react in Melzer's reagent (vs. become pink to orange red in G. albidum; Walker, Rhodes 1981).

Two characters of spores of $G$. gibbosum readily separate this fungus from G. eburneum. First, while spores of the former species occur in the soil singly, in loose aggregates and conglomerations enclosed by a common hyphal mantle (Błaszkowski 1997, 2003), the latter fungus produces only single spores (Fig. 1). Second, the spore wall of G. eburneum comprises only two layers (Figs 2-5), and that of G. gibbosum consists of four layers (Błaszkowski 2003). The spore wall of G. eburneum lacks the wall layers 2 and 4 of spores of $G$. gibbosum.

Spores of $G$. viscosum are also frequently formed in loose aggregates (Morton 2002; vs. only single spores in G. eburneum; Fig. 1) and have a more complex wall structure (3-layered) than those of G. eburneum (2-layered; Figs 2-5). The spore wall layer of G. viscosum not synthesized by G. eburneum is the permanent, semi-flexible, thin layer positioned between a semi-flexible layer forming the spore surface and a laminate layer, both phenotypically similar to the spore wall layers 1 and 2 , respectively, of G. eburneum.

As far as the species compared here are concerned, the fungus most diverged morphologically from G. eburneum is Paraglomus occultum. These species share only their outermost spore wall layer (Morton 2002; Morton, Redecker 2001). Although these layers in both fungi are of the type of impermanent layers, the longevity of the layer in G. eburneum is much higher than in P. occultum, in which it usually highly deteriorates with age to form a granular structure (Morton 2002), a phenomenon not found in G. eburneum (Figs 2-6). The two other spore wall layers of $P$. occultum are uniform and much thinner (both $<0.5-1.2 \mu \mathrm{m}$ thick) than the inner laminate spore wall layer of G. eburneum [(2.5-)3.5(-4.4) $\mu \mathrm{m}$ thick].

As mentioned above, darker-coloured spores of G. eburneum may also overlap in colour and appearance with light-coloured spores of $G$. claroideum and $G$. versiforme. However, the former two fungi differ fundamentally in the construction of their spore wall, as well as in the phenotypic and biochemical properties of its components. Compared with the simple, 2-layered spore wall of G. eburneum (Figs 2-6), that of G. claroideum comprises four layers with the innermost layer staining in Melzer's reagent (Błaszkowski 2003; Morton 2002; Stürmer, Morton 1997; vs. none of the spore wall layers of G. eburneum reacts in this reagent; Fig. 4). The only layers of the spore wall of $G$. claroideum sharing the phenotypic and biochemical 
properties of layers 1 and 2 of the G. eburneum spore wall are its layers 2 and 3, respectively. The distinctive component of the spore wall of G. claroideum is the innermost flexible layer, which is lacking in G. eburneum.

Light-coloured spores of $G$. versiforme may be indistinguishable from mature spores of G. eburneum when observed under both a dissecting and a compound microscope. Apart from colour, spores of the two species are almost identical in size, as well as in the construction and the phenotypic and biochemical properties of the components of their wall. Moreover, mycorrhizae of both species stain faintly in $0.1 \%$ trypan blue (Figs 7 and 8; Błaszkowski, pers. observ.; Morton 2002). The only property distinguishing $G$. eburneum and $G$. versiforme is the formation of sporocarps by the latter fungus (Morton 2002).

Apart from the morphological differences characterized above, the species compared here also differ in the phylogenetic position within the phylum Glomeromycota determined based on results of their molecular analyses. For example, G. claroideum and G. viscosum represent Glomus group B in the family Glomeraceae Piroz. et Dalpé of the order Glomerales J.B. Morton et Benny, and Par. occultum, originally described as G. occultum C. Walker, presently is a member of the family Paraglomaceae J.B. Morton et D. Redecker in the Paraglomerales C. Walker et Schuessler (Schüßler, Schwarzott and Walker 2001). As presented in the section "Phylogenetic position", G. eburneum should be a member of the family Diversisporaceae, as Gamber and Leuchtmann (2007) found. Unfortunately, the phylogenetic positions of G. albidum and $G$. gibbosum are unknown to date.

Scutellospora fulgida Koske et C. Walker

Spores formed singly in the soil; origin blastically at the tip of a bulbous sporogenous cell; yellowish white (4A2) to cream (4A3); globose to subglobose; (165-)229 (-280) $\mu \mathrm{m}$ diam (Fig. 9). Subcellular structure of spores consists of a spore wall and one inner germination wall (Figs 10-13). Spore wall composed of two layers (layers 1 and 2; Figs 10, 11, 13 and 14). Layer 1, forming the spore surface, permanent, smooth, pale yellow (3A3) to light orange (5A5), (1.2-)2.0(-3.2) $\mu \mathrm{m}$ thick, usually tightly adherent to layer 2 , sometimes slightly separated from it in vigorously crushed spores. Layer 2 laminate, smooth, yellowish white (4A2) to cream (4A3), (7.6-)9.7 $(-13.0) \mu \mathrm{m}$ thick. Germination wall comprises two flexible, smooth layers (layers 1 and 2; Figs 10-13). Layer 1 ca. $0.5 \mu \mathrm{m}$ thick, adherent to layer 2, but frequently wrinkled in crushed spores and, thereby, giving the inner wall a rugose or blistered appearance and making this layer more visible. Layer 2 0.8-1.5 $\mu \mathrm{m}$ thick. In Melzer's reagent, the spore wall layers 1 and 2 stain orange white (5A2) to copper (7C8) and pale yellow (3A3) to reddish orange (7B7), respectively, and both germination wall layers remain nonreactive (Figs 11-14). Sporogenous cell formed terminally on a sparsely septate hypha continuous with an extraradical mycorrhizal hypha; ovoid to clavate; (38.7-)44.6(-53.2) $\mu \mathrm{m}$ wide; cream (4A3) to light orange (5A5), usually with a hyphal peg (Figs 9 and 14). Wall of sporogenous cell composed of two permanent layers (layers 1 and 2) continuous with spore wall layers 1 and 2 (Fig. 14). Layer 1 pale yellow (3A3) to light orange (5A5), (1.7-)2.4(-3.2) $\mu \mathrm{m}$ thick. Layer 2 cream (4A3) to light yellow (4A4), (1.5-)2.6(-3.9) $\mu \mathrm{m}$ thick at the spore base. Both layers always tightly adherent to one another and difficult to observe. Germination shield cardioid; pale yellow (3A3); 60-120 x 110-190 $\mu \mathrm{m}$, of a more or less incised border; 
ornamented with widely usually unequally dispersed warts, $1.5-2.5$ x 0.5-1.5 $\mu \mathrm{m}$; positioned on the upper surface of the inner germination wall (Fig. 15). One to three germ tubes or germ tube initials emerge from the germination shield. Auxiliary cells borne in the soil, in clusters of 6-10; hyaline to cream (4A3); globose to irregular; 18-28 x 23-39 $\mu \mathrm{m}$; with knobby projections; produced on straight or coiled hyphae; 2.5-8.0 $\mu \mathrm{m}$ diam; concolorous with auxiliary cells (Fig. 16).

MYCORRHIZAL ASSOCIATIONS. The presence of mycorrhizae in field-collected root samples was not determined. Many attempts to growth this fungus in one-species cultures failed. According to Morton (2002), S. fulgida formed mycorrhizae with arbuscules and intraradical hyphae staining intensively in trypan blue.

Distribution AND HABITAT. The spores of $S$. fulgida showed here were extracted from six trap cultures with rhizosphere soils and root fragments collected under plants colonizing maritime dunes of Portugal (four samples), Italy and Oman (one sample each). The occurrence of arbuscular fungi in the field soil-root mixtures was not determined. The field samples from Italy came from under Ammophila arenaria (L.) Link and were collected on 11 October 2002. The exact sites and dates of collections of the soil and root samples, as well as the host plants sampled in Portugal and Oman are unknown. The trap cultures with these samples were established on 8 March 2004 and 30 June 2003, respectively, i. e., some days after they arrived to the laboratory of the author of this paper. The arbuscular fungi accompanying $S$. fulgida in the cultures representing Italy were Acaulospora scrobiculata Trappe, Intraspora schenckii (Sieverd. et S. Toro) Oehl et Sieverd., Glomus aurantium Błaszk., V. Blanke, C. Renker et F. Buscot, G. constrictum Trappe, G. versiforme (P. Karsten) S.M. Berch, an undescribed Glomus 169, and S. persica (Koske et C. Walker) C. Walker et F.E. Sanders. The only arbuscular fungus co-occurring with S. fulgida in the Portugal culture was an undescribed Glomus 172, and the culture with the rhizosphere soil and root mixture of Oman still contained spores of G. fasciculatum (Thaxt.) Gerd. et Trappe emend. C. Walker et Koske and S. persica.

The type of $S$. fulgida comes from field-collected spores isolated from under A. breviligulata Fern. colonizing maritime dunes of the Seashore State Park in Virginia, U.S.A. (Koske and Walker 1986). This fungus has also been found in other soil samples taken from under $A$. breviligulata, Solidago sempervirens L., and Uniola paniculata L. growing in dunes extending from New Jersey to Virginia (Koske 1987). Sylvia and Will (1988) found spores of $S$. fulgida associated with $U$. paniculata and Panicum sp. growing in soils of a beach replenishment site in Florida. Additionally, S. fulgida has been reported to occur under Triticum aestivum L. cultivated in Argentina (Schalamuk et al. 2006) and in soils of China (Gai et al. 2006).

Collections EXAmined. Poland: Szczecin, all from trap cultures with $P$. lanceolata as the host plant and rhizosphere soils and root fragments of $A$. arenaria sampled (1)

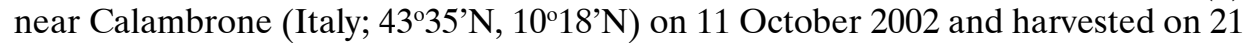
June 2006, Błaszkowski J. 2697-2701 (DPP); (2) in Oman, harvested on 15 March 2003, Błaszkowski J. 2702-2708 (DPP); and (3) in Portugal, harvested on 22 July 2006, Błaszkowski J. 2709-2716 (DPP).

Notes. The distinctive characters of $S$. fulgida are its light-coloured spores of a smooth surface and the sinthesization of only one inner germination wall (Figs 9-13). The last property keys this fungus into a monophyletic group still comprising S. castanea C. Walker, S. coralloidea (Trappe, Gerd. et H.H. Ho) C. Walker et F.E. 
Sanders, S. gregaria (N.C. Schenck et Nicol.) C. Walker et F.E. Sanders, S. persica (Koske et C. Walker) C. Walker et F.E. Sanders, and S. verrucosa (Koske et C. Walker) C. Walker et F.E. Sanders.

Four spore characters readily separate the species listed above. First, spores of S. fulgida are much lighter-coloured than those of the other species compared here (cream to light orange in S. fulgida (Figs 9 and 10) vs. from pale straw to orange brown in $S$. verrucosa to red brown to dark brown in S. gregaria; Morton 1995, 2002). Second, in contrast to the smooth spores of $S$. castanea (Walker, Gianinazzi-Pearson and Marion-Espinasse 1993) and S. fulgida (Figs 9-14), the spore surface of the other species is ornamented with warts (Morton 1995, 2002). However, S. fulgida and $S$. castanea markedly differ in colour and size of spores. The darkest spores of the former fungus are of a yellow shade, and mature spores of the latter species are brown (Walker, Gianinazzi-Pearson and Marion-Espinasse 1993). Third, although the lower size range of globose spores of $S$. fulgida and $S$. castanea overlaps, the largest spores of $S$. fulgida $(280 \mu \mathrm{m}$ diam) are much smaller than the greatest spores of S. castanea (up to $372 \mu \mathrm{m}$ diam; Walker, Gianinazzi-Pearson and Marion-Espinasse 1993). Spores of the other species discussed here may also attain a much higher size than those of $S$. fulgida (384 $\mu \mathrm{m}$ diam in $S$. persica to $480 \mu \mathrm{m}$ diam in S. gregaria; Morton 1995). Fourth, similarly as in $S$. castanea, the warts ornamenting the germination shield of $S$. fulgida spores are much lower and less densely dispersed on its surface (Fig. 15) compared with those ornamenting the germination shield of the other species. This also causes the germination shields of the former two species to be relatively more flexible, as Morton (1995) concluded.

Acknowledgements. This study was supported in part by the Committee of Scientific Researches, a grant no. 2 P04C 04128.

\section{REFERENCES}

Błaszkowski J. 1997. Glomus gibbosum, a new species from Poland. Mycologia 89: 339-345.

Błaszkowski J. 2003. Arbuscular mycorrhizal fungi (Glomeromycota), Endogone and Complexipes species deposited in the Department of Plant Pathology, University of Agriculture in Szczecin, Poland. http://www.agro.ar.szczecin.pl/ jblaszkowski/.

Błaszkowski J., Blanke V., Renker C., Buscot F. 2004. Glomus aurantium and G. xanthium, new species in Glomeromycota. Mycotaxon 90: 447-467.

Błaszkowski J., Kowalczyk S., Czerniawska B. 2006. Acalospora rehmii and Gigaspora margarita, arbuscular mycorrhizal fungi (Glomeromycota) new for Europe and Poland, respectively. Acta Mycol. 41: 41-48.

Gai J. P., Christie P., Feng G., Li X. L. 2006. Twenty years of research on biodiversity and distribution of arbuscular mycorrhizal fungi in China: a review. Mycorrhiza 16: 229-239.

Gamber H., Leuchtmann A. 2007. Taxon-specific PCR primers to detect two inconspicuous arbuscular mycorrhizal fungi from temperate agricultural grassland. Mycorrhiza 17: 145-152.

Gilmore A. E. 1968. Phycomycetous mycorrhizal organisms collected by open-pot culture methods. Hilgardia 39: 87-105.

Kennedy L. J., Stutz J. C., Morton J. B. 1999. Glomus eburneum and G. luteum, two new species of arbuscular mycorrhizal fungi, with emendation of G. spurcum. Mycologia 91: 1083-1093.

Kornerup A., Wanscher J. H. 1983._Methuen handbook of_colour. 3rd Ed. E. Methuen and Co., Ltd., London. 252 pp.

Koske R. E. 1987. Distribution of VA mycorrhizal fungi along a latitudinal temperature gradient. Mycologia 79: 55-68. 
Koske R. E., Walker C. 1986. Species of Scutellospora (Endogonaceae) with smooth-walled spores from maritime sand dunes: two new species and a redescription of the spores of Scutellospora pellucida and Scutellospora calospora. Mycotaxon 27: 219-235.

Mirek Z. H, Piękoś-Mirkowa H., Zając A., Zając M. 1995. Vascular plants of Poland. A Checklist. Polish Botanical Studies, Guidebook 15, Kraków, 303 pp.

Morton J. M. 1995. Taxonomic and phylogenetic divergence among five Scutellospora species based on comparative developmental sequences. Mycologia 87: 127-137.

Morton J. B. 2002. International Culture Collection of (Vesicular) Arbuscular Mycorrhizal Fungi. West Virginia University: http://www.invam.caf.wvu.edu/.

Morton J. B., Redecker D. 2001. Two families of Glomales, Archaeosporaceae and Paraglomaceae, with two new genera Archaeospora and Paraglomus, based on concordant molecular and morphological characters. Mycologia 93: 181-195.

Omar M. B., Bollan L., Heather W. A. 1979. A permanent mounting medium for fungi. Bull. Brit. Mycol. Soc. 13: 31-32.

Schalamuk S., Velazquez S., Chidichimo H., Cabello M. 2006. Fungal spore diversity of arbuscular mycorrhizal fungi associated with spring wheat: effect of tillage. Mycologia 98: 16-22.

Schüßler A., Schwarzott D., Walker C. 2001. A new fungal phylum, the Glomeromycota: phylogeny and evolution. Myc. Res. 105: 1413-1421.

Schwarzott D., Walker C., Schüßler A. 2001. Glomus, the largest genus of the arbuscular mycorrhizal fungi (Glomales) is nonmonophyletic. Mol. Phyl. Evol. 21: 190-197.

Spain J. L., Sieverding E., Oehl F. 2006. Appendicispora: a new genus in the arbuscular mycorrhiza-forming Glomeromycetes, with a discussion of the genus Archaeospora. Mycotaxon 97: 163-182.

Stürmer S. L., Morton J. B. 1997. Developmental patterns defining morphological characters in spores of four species in Glomus. Mycologia 89: 72-81.

Stutz J. C., Copeman R., Martin C. A., Morton J. B. 2000. Patterns of species composition and distribution of arbuscular mycorrhizal fungi in arid regions of southeastern North America and Namibia, Africa. Can. J. Bot. 78: 237-245.

Stutz J. C., Morton J. B. 1996. Successive pot cultures reveal high species richness of arbuscular mycorrhizal fungi in arid ecosystems. Can. J. Bot. 74: 1883-1889.

Sylvia D. M., Will M. E. 1988. Establishment of vesicular-arbuscular mycorrhizal fungi and other microorganisms on a beach replenishment site in Florida. Appl. Environ. Microbiol. 54: 348-352.

Walker C. 1983. Taxonomic concepts in the Endogonaceae: Spore wall characteristics in species descriptions. Mycotaxon 18: 443-455.

Walker C., Gianinazzi-Pearson V., Marion-Espinasse H. 1993. Scutellospora castanea, a newly described arbuscular mycorrhizal fungus. Cryptog. Mycol. 14: 279-286.

Walker C., Rhodes L. H. 1981. Glomus albidus: a new species in the Endogonaceae. Mycotaxon 12: 509-514.

Walker C., Schüßler A. 2004. Nomenclatural clarifications and new taxa in the Glomeromycota. Mycol. Res. 108: 979-982.

Walker C., Trappe J. M. 1993. Names and epithets in the Glomales and Endogonales. Mycol. Res. 97: 339-344.

Walker C., Vestberg M. 1994. A simple and inexpensive method for producing and maintaining closed pot cultures of arbuscular mycorrhizal fungi. Agr. Sci. Finland 3: 233-240.

\section{Glomus eburneum i Scutellospora fulgida, nowe dla Europy gatunki mikoryzowych grzybów arbuskularnych (Glomeromycota)}

Streszczenie

Opisano i zilustrowano cechy morfologiczne zarodników i mikoryz Glomus eburneum oraz zarodników Scutellospora fulgida, mikoryzowych grzybów arbuskularnych z gromady Glomeromycota. Ponadto przedstawiono poznane rozmieszczenie tych gatunków zarówno w Polsce, jak i innych regionach świata. Oba te gatunki nie były wcześniej podawane z Europy. 




Figs 1-8. Glomus eburneum. 1. Intact spores. 2. Spore wall layers 1 (swl1) and 2 (swl2) and subtending hypha. 3 and 4 . Spore wall layers 1 (swl1) and 2 (swl2). 5. Spore wall layers 1 (swl1) and 2 (swl2), subtending hyphal wall layers 1 (shwl1) and 2 (shwl2), and curved septum. 6. Subtending hypha occluded by curved septum. 7 and 8 . Arbuscules, trunk, intraradical hyphae, and coil of mycorrhizae stained in $0.1 \%$ trypan blue. Fig. 1, spores in lactic acid. Figs 2, 3, 5-8, spores crushed in PVLG. Fig. 4, spore crushed in PVLG+Melzer's reagent. Fig. 1, bright field microscopy. Figs 2-8, differential interference contrast. 

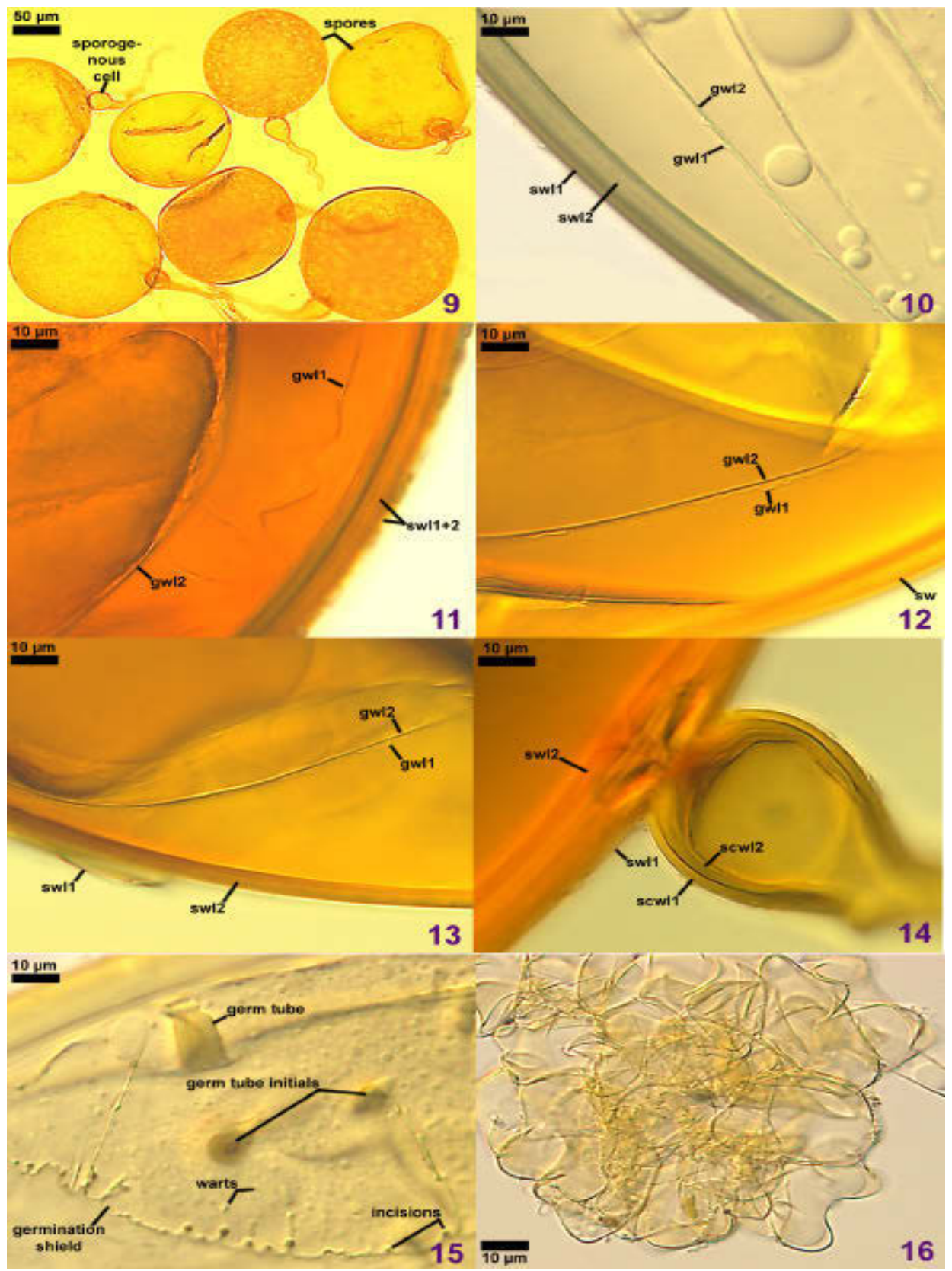

Figs 9-16. Scutellospora fulgida. 9. Intact spores with bulbous sporogenous cells. 10-13. Spore wall layers 1 (swl1) and 2 (swl2) and inner germination wall layers 1 (gwl1) and 2 (gwl2). 14. Spore wall layers 1 (swl1) and 2 (swl2) and sporogenous cell wall layers 1 (scwl1) and 2 (scwl2). 15. Germination shield with germ tube and two germ tube initials. Fig. 9, spores in lactic acid. Figs 10 and 16, spores crushed in PVLG. Figs 11-15, spores crushed in PVLG+Melzer's reagent. Fig. 9, bright field microscopy. Figs 10-16, differential interference contrast. 